\author{
Journal of Current and Advance Medical Research \\ January 2018, Vol. 5, No. 1, pp. 7-10 \\ http://www.banglajol.info/index.php/JCAMR \\ ISSN (Print) 2313-447X \\ ISSN (Online) 2413-323X \\ DOI: http://dx.doi.org/10.3329/jcamr.v5i1.36538
}

ORIGINAL ARTICLE

OPEN ACCESS

\title{
Sexual Dimorphism in Total Length of Fully Ossified Dry Human Left Tibia
}

\author{
Mahbuba Akter ${ }^{1}$, Fahmida Zaman ${ }^{2}$, Israt Jahan Tania ${ }^{3}$, Soniya Fahmi ${ }^{4}$, Omma Hafsa Any ${ }^{5}$
}

\begin{abstract}
${ }^{1}$ Assistant Professor, Department of Anatomy, ZH Sikder Women's Medical College, Dhaka, Bangladesh; ${ }^{2}$ Assistant Professor, Department of Anatomy, MH Somorita Medical College, Dhaka, Bangladesh; ${ }^{3}$ Assistant Professor, Department of Anatomy, City Dental College, Dhaka, Bangladesh; ${ }^{4}$ Assistant Professor, Department of Biochemistry, ZH Sikder Women's Medical College, Dhaka, Bangladesh; ${ }^{5}$ Associated Professor, Department of Pharmacology and Therapeutics, Z.H.Sikder Women's Medical College, Dhaka, Bangladesh
\end{abstract}

[Reviewed: 30 August 2017; Accepted on: 1 November 2017; Published on: 1 January 2018]

\section{Abstract}

Background: Determination of sex from skeletal remains is one of the important aspects of Osteometric analysis. Objectives: The present study was planned to collect data regarding total length of fully ossified dry human left tibia and to find out possible variations in male and female. Methodology: This analytical type of cross-sectional study was conducted in the Department of Anatomy at Sir Salimullah Medical College, Dhaka, Bangladesh from July 2014 to June 2015 for a period of one year. In this study fully ossified dry human left tibia of unknown sex were collected from In this study fully ossified dry human left tibia of unknown sex were collected from the department of Anatomy and also from the students of Sir Salimullah Medical College (SSMC), Dhaka, Ibrahim Medical College (IMC), Dhaka, Dhaka National Medical College (DNMC), Dhaka and Bangladesh Medical College (BMC), Dhaka. The study samples were distributed in male and female sex groups by discriminate function analysis. Total lengths were measured with the help of an osteometric board. Results: A total number of two hundred (200) fully ossified dry human left tibia of unknown sex were analyzed. The mean $( \pm \mathrm{SD})$ values of total length were greater in male $(38.82 \pm 2.94) \mathrm{cm}$ than female $(33.48 \pm 1.68)$ which was statically significant $(\mathrm{p}<0.001)$. Conclusion: In conclusion the total length is greater in male compared to female. [Journal of Current and Advance Medical Research 2018;5(1):7-10]

Keywords: Total length; discriminant function analysis; sex differentiation

Correspondence: Dr. Mahbuba Akter, Assistant Professor, Department of Anatomy, Z.H Sikder Women's Medical College, Dhaka, Bangladesh; Email: mahbubaaveekbd@gmail.com; Cell No.: +8801850074765

Cite this article as: Akter M, Zaman F, Tania IJ, Fahmi S, Any OH. Sexual Dimorphism in Total Length of Fully Ossified Dry Human Left Tibia. J Curr Adv Med Res 2018;5(1):7-10

Conflict of interest: We do not have any conflict of interest (financial or other)

Funding: This research project was not funded by any group or any institute on.

Contributions to authors: All author designed the study, deduced the data and revised it acquired the data, conducted the data analysis, interpreted the data and revised the manuscript, also participated in the language editing. All author participated in data analysis, interpreted the data revised. All the authors approved the final document.

Copyright: @2018 Akter et al. Published by Journal of Current and Advance Medical Research. This article is published under the Creative Commons CC BY-NC License (https://creativecommons.org/licenses/by-nc/4.0/). This license permits use, distribution and reproduction in any medium, provided the original work is properly cited, and is not used for commercial purposes. 


\section{Introduction}

Sex estimation is one of the prime factors which are employed to establish the identity of a person ${ }^{1}$. In human body, tibia is the stronger and second largest bone next to femur. It is commonly recognized as the large weight bearing bone of the leg. The knee joint has a screw-home mechanism, where the joint is locked during the process of extension and is then unlocked during the process of flexion ${ }^{2}$. Overuse injuries of knee include tendinitis, bursitis, muscle sprains and ilio-tibial band syndrome. Extensive knowledge of morphological variation of tibial plateau can lead us to better prevention and preparation of possible surgical interventions of knee $^{3}$. The thick shell is the cortical part of bone, which provides most of the mechanical strength. A tibial stress fracture or "hairline fracture is caused by repeated bending, usually from weight-bearing activity $^{4}$. Medial tibial stress syndrome or shin splints are commonly seen in athletes who suddenly increase their duration or intensity of regular practice training ${ }^{5}$. Location and number of nutrient foramina in long bone is important in orthopedic surgical procedure such as joint replacement therapy, fracture repair, bone grafts and vascularized bone microsurgery as well as in medico legal cases ${ }^{6}$. Fracture of tibia is relatively common and occurs most frequently in middle aged and elderly people. Fracture of tibia can be divided into Bumper fracture, Segond fracture, Gosselin fracture, Toddler's fracture. Fracture of tibia is among the most serious long bone fracture, due to their potential for nonunion, mal-union and longterm dysfunction as well as their propensity for open injury ${ }^{7}$. Intra-medullary nailing is the gold standard treatment option for displaced closed or open tibial diaphyseal fracture ${ }^{8}$.

The bone in female slants down and slightly outward in each leg as the result of women typically having wider hips than men. Sex estimation is one of the prime factors which are employed to establish the identity of a person ${ }^{9}$. The anthropometric study of bone is important to determine race and also in medico legal cases for determination of sex. Tibia is an ideal long bone of the limb which is used for sex determination, as it resists erosive forces which act upon it and it remains unaffected even after burial of body ${ }^{10}$.

Total length of tibia is by far the best single variable for estimation of sex. So far it is known the morphometric measurement of tibia have not yet been studied in Bangladesh. This study was undertaken to measure the total length of left tibia and to evaluate the difference in total length of the same between male and female.

\section{Methodology}

This analytical type of cross-sectional study was conducted in the Department of Anatomy at Sir Salimullah Medical College, Dhaka, Bangladesh from July 2014 to June 2015 for a period of one years. Dry left sided adult human tibia of unknown sex were collected from the Department of Anatomy and also from the students of Sir Salimullah Medical College (SSMC), Dhaka, Ibrahim Medical College (IMC), Dhaka, Dhaka National Medical College (DNMC), Dhaka and Bangladesh Medical College (BMC), Dhaka. Then the sex was determined by linear discriminant function analysis technique ${ }^{8}$. This linear discriminant function analysis technique was applied to the collected data in as follows: $Z=b_{0+} b_{1}$ $\mathrm{x}_{1}$; Here $\mathrm{Z}=$ Discriminant function, $\mathrm{b}_{0}=$ Constant*, $\mathrm{b}_{1}=$ Co- efficient $*$ and $\mathrm{x}_{1}=$ Total length of left tibia (independent variable).

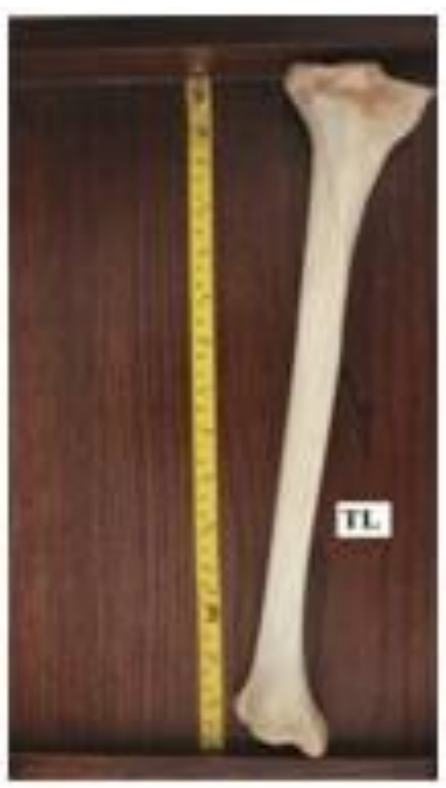

\section{Figure I: Photograph showing total length of tibia by osteometric board; $T L=$ total length}

In this study the value of $\mathrm{Z}$ for each specimen was calculated by substituting the values of the variables in the linear function. A sectioning point was created by using the mean discriminant scores which were also known as the group centroids. To assign the case to either male or female sex the product $\mathrm{Z}$ was compared to the sectioning point deprived by the discriminant function analysis. A value higher than the sectioning point was considered to be male and a value below it was considered to be female. By discriminant analysis 
technique the sex was determined and the grouping was done. Afterwards for the measurement of total length of tibia, the straight distance from lateral condyle to the tip of medial malleolus were determined by osteometric board (Figure I). After collection of data, the findings of the study was analyzed by SPSS version 20.0 and revealed important information regarding morphometric variation. Comparison of the values of different variables between male and female was done by unpaired Students ' $t$ ' test. This study was approved by the Institutional Ethics Committee (IEC) of Sir Salimullah Medical College, Dhaka.

\section{Results}

A total number of two hundred (200) dry left sided adult human tibia of unknown sex were collected The fully ossified dry human left tibia were grouped into male and female by discriminant function analysis technique (Table 1).

Table 1: Distribution of Study Subjects into Different Sex According to Discriminant Functional Analysis Technique

\begin{tabular}{|l|c|c|}
\hline Gender & Frequency & Percentage \\
\hline Male & 102 & 51 \\
\hline Female & 98 & 49 \\
\hline Total & $\mathbf{2 0 0}$ & $\mathbf{1 0 0 . 0}$ \\
\hline
\end{tabular}

The range of total length of tibia was $34.61 \mathrm{~cm}$ to $46.76 \mathrm{~cm}$ in male and $31.11 \mathrm{~cm}$ to $39.94 \mathrm{~cm}$ in female. The mean $( \pm \mathrm{SD})$ value of total length was $38.82( \pm 2.94) \mathrm{cm}$ in male and $33.48( \pm 1.68) \mathrm{cm}$ in female. There was significant difference between total length $(\mathrm{p}=0.000)$ (Figure II).

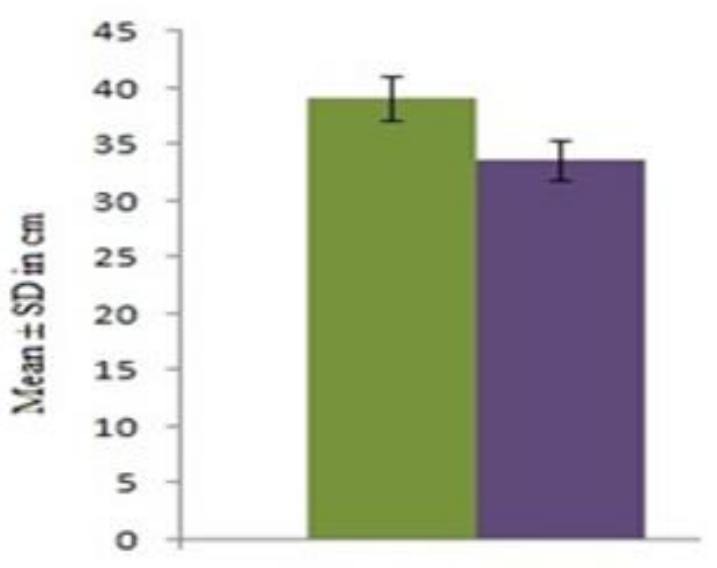

Figure II: Bar diagram showing total length of left tibia in male $(n=102)$ and female $(n=98)$

\section{Discussion}

In the present study the mean $( \pm \mathrm{SD})$ of total length of tibia was found greater in male than female which was statistically significant $(\mathrm{p}<0.01)$. This finding which was similar to the study represented by Fernandez et $\mathrm{al}^{11}$ who carried out study on the Ireland population; Kuykendall et $\mathrm{al}^{12}$ on the South African; Tomicic et $\mathrm{at}^{13}$ on the Croatian population. Fernandez et $\mathrm{al}^{11}$ conducted a study on skeletal remains in Ireland population. For this purpose they collected 59 tibias (45 male and 14 female) and had reported the mean $( \pm \mathrm{SD})$ maximum length of tibia was $36.91 \pm 2.626 \mathrm{~cm}$ and $33.47 \pm 1.38 \mathrm{~cm}$ in male and female respectively. Kuykendall et $\mathrm{al}^{8}$ conducted a study on South African Whites for sexual dimorphism. A total number of 169 tibia were measured according to standard osteometric technique. The mean $( \pm \mathrm{SD})$ of total length of tibia was $38.25 \pm 2.36 \mathrm{~cm}$ and $35.21 \pm 1.99 \mathrm{~cm}$ in male and female respectively. Tomicic et at ${ }^{13}$ conducted a study on medieval Croatian population. A total number of 180 tibias (96 males and 84 females) were measured according to standard osteometric technique. The mean $( \pm \mathrm{SD})$ of total length of tibia was $38.22 \pm 2.140 \mathrm{~cm}$ and $34.91 \pm 1.96 \mathrm{~cm}$ in male and female respectively. The measured values of the present study was found significantly dissimilar $(\mathrm{p}<0.01)$ to the findings reported by Mahajan, Seema ${ }^{14}$ and Sirisha et ${ }^{15}$ al who worked on the Indian population. Though there was racial similarity but the values of this study showed somewhat contrary $(\mathrm{P}<0.01)$.

The present study was carried out in tibia collected from Bangladesh. Skeletons that are available in Bangladesh also come from neighboring countries. Bangladeshis are mixed race of Caucasoid, Negroid, Mongoloid and Australoid group. However the total length in present study was nearly similar to the mean values of other researchers.

\section{Conclusion}

This study reveals that the total length of tibia is greater in male than female. The differences in length can be useful in sex differentiation. Further radiographic study of living tibia and comparison of the radiographic findings of fully ossified dry human left tibia might be beneficial in this study.

\section{References}

1. Rai N, Nair S, Bankwar V, Rai N, Thanduri K. Sex determination of adult human tibia in central Indian 
population. International Journal of Medical and Health Research, 2017;3(5):82-84

2. Wang J, Tao K, Li H, Wang C. Modelling and analysis on biomechanical dynamic characteristics of knee flexion movement under squatting. The Scientific World Journal. 2014;2014

3. Ioan-Mohor Co. Morphometric Study of The Proximal Extremity Of The Tibia. Acta Medica Transilvanica 2014;19(2):271-273

4. Devis J. Injury Series: Tibial stress fractures and stress reactions: The role of bone structure, impact, and calf strength . 2014 May 23 ;2014 [Web address: http://www.runningwritings.com/2012/05/injury-seriestibial-stress-fractures.html]

5. Clutte, J. Shin splints. IOSR Journal of Pharmacy and Biological Sciences 2014; 2014

6. Morandi M, Banka T, Gaiarsa GP, Guthrie ST, Khalil J, Hoegler J. Intramedullary nailing of tibial fractures: review of surgical techniques and description of a percutaneous lateral suprapatellar approach. Orthopedics. 2010;33(3)

7. Mahajan A. Determination of Sex from the Tibia in the Punjab Zone. Journal of Clinical \& Diagnostic Research. 2012;6(6)
8. Özer BK, Özer İ, Sağir M, Güleç E. Sex Determination Using The Tibia In An Ancient Anatolian Population. Mediterranean Archaeology \& Archaeometry. 2014;14(2)

9. Soni G, Dhall U, Chhabra S. Determination of sex from femur: discriminant analysis. $J$ Anat Soc India. 2010;59(2):216-21

10. Shamsunder Rao V, Kothapalli J. The diaphyseal nutrient foramina architecture--a study on the human upper and lower limb long bones. IOSR J Pharm Biol Sci. 2014;9(1):36-41

11. González-Reimers E, Velasco-Vázquez J, Arnay-De-LaRosa M, Santolaria-Fernández F. Sex determination by discriminant function analysis of the right tibia in the prehispanic population of the Canary Islands. Forensic science international. 2000;108(3):165-72

12. Dayal MR, Steyn M, Kuykendall KL. Stature estimation from bones of South African whites. South African Journal of Science. 2008;104(3-4):124-8

13. Šlaus M, Bedić Ž, Strinović D, Petrovečki V. Sex determination by discriminant function analysis of the tibia for contemporary Croats. Forensic science international. 2013;226(1-3):302-e1

14. Blaga L. Morphometric study of proximal extremity of tibia. Acta Medica Transilvanica 2014 June ;2014 